\title{
Comparison of rumen bacterial communities in dairy herds of different production
}

\author{
Nagaraju Indugu', Bonnie Vecchiarelli', Linda D. Baker ${ }^{1}$, James D. Ferguson' ${ }^{1}$, Jairam K. P. Vanamala ${ }^{2,3}$
} and Dipti W. Pitta ${ }^{1 *}$

\begin{abstract}
Background: The purpose of this study was to compare the rumen bacterial composition in high and low yielding dairy cows within and between two dairy herds. Eighty five Holstein dairy cows in mid-lactation (79-179 days in milk) were selected from two farms: Farm 12 (M305 = 12,300 kg; $n=47 ; 24$ primiparous cows, 23 multiparous cows) and Farm 9 (M305 = 9700 kg; $n=38 ; 19$ primiparous cows, 19 multiparous cows). Each study cow was sampled once using the stomach tube method and processed for $16 \mathrm{~S}$ rRNA gene amplicon sequencing using the lon Torrent (PGM) platform.

Results: Differences in bacterial communities between farms were greater (Adonis: $R^{2}=0.16 ; p<0.001$ ) than within farm. Five bacterial lineages, namely Prevotella (48-52\%), unclassified Bacteroidales (10-12\%), unclassified bacteria (5-8\%), unclassified Succinivibrionaceae (1-7\%) and unclassified Prevotellaceae (4-5\%) were observed to differentiate the community clustering patterns among the two farms. A notable finding is the greater $(p<0.05)$ contribution of Succinivibrionaceae lineages in Farm 12 compared to Farm 9. Furthermore, in Farm 12 , Succinivibrionaceae lineages were higher $(p<0.05)$ in the high yielding cows compared to the low yielding cows in both primiparous and multiparous groups. Prevotella, S24-7 and Succinivibrionaceae lineages were found in greater abundance on Farm 12 and were positively correlated with milk yield.

Conclusions: Differences in rumen bacterial populations observed between the two farms can be attributed to dietary composition, particularly differences in forage type and proportion in the diets. A combination of corn silage and alfalfa silage may have contributed to the increased proportion of Proteobacteria in Farm 12. It was concluded that Farm 12 had a greater proportion of specialist bacteria that have the potential to enhance rumen fermentative digestion of feedstuffs to support higher milk yields.
\end{abstract}

Keywords: Dairy cows, Rumen microbiota, Dairy herds

\section{Background}

Nearly $70 \%$ of energy [1] and $60-85 \%$ of protein [2] requirements of the dairy cow are met from microbial fermentation, indicating a critical need for maximizing rumen function and describing rumen microbiota. However, it is still not known how diet and microbes interact

\footnotetext{
* Correspondence: dpitta@vet.upenn.edu

'Department of Clinical Studies, School of Veterinary Medicine, New Bolton Center, University of Pennsylvania, Kennett Square, PA 19348, USA

Full list of author information is available at the end of the article
}

to enhance milk yields in dairy cows. Typically, dairy herds are fed total mixed rations (TMR) and cows with greater milk production have greater dry matter intake (DMI) [3]. In TMRs for dairy cattle, carbohydrates constitute nearly $70 \%$ of the dietary dry matter (DM) and provide the major energy source for rumen microbes $[4,5]$. Carbohydrates may be broadly classified into two distinct groups based on their solubility in neutral detergent $[6,7]$. Neutral detergent fiber (NDF) is insoluble in neutral detergent solution and is composed of cellulose, hemicellulose and lignin. Cellulose and hemicellulose are fiber carbohydrates (FC) predominantly 
found in forages. FC ferment slowly and are important in regulating rumen function through formation of the rumen mat and influencing the rate of passage out of the rumen. Non-Fiber Carbohydrates (NFC) are soluble in neutral detergent solution and include sugars, starch, beta-glucans and pectins, which ferment more rapidly in the rumen [7]. To maintain a stable rumen environment and enhance microbial growth, a minimum NDF and a maximum NFC (\% diet DM) are needed in high producing dairy cow diets. Excessive NFC can create acidosis, while excessive NDF and low NFC can constrain feed intake and milk production [8]. The proportion of NDF and NFC in the diet, the composition of NFC components, and the extent to which these carbohydrates ferment in the rumen can influence the ruminal microbiota $[9,10]$.

Corn silage represents a major feed resource and often comprises $50 \%$ to $70 \%$ of forage in diets in the Northeastern US [11, 12]. Dairy One (Ithaca, NY), a commercial laboratory, reports that NDF averaged $44.2 \%$ DM (SD 5.3) and starch 30.7\% DM (SD 6.5) in 11,281 corn silage samples analyzed between May 1, 2014 and April 30, 2015 (http://dairyone.com/2016-fresh-cornsilage-results-ny-and-pa/). Corn silage is classified as forage, however contains varying amounts of grain, contributing both dietary NDF and starch [8]. Concentrations of NDF and starch in corn silage are dependent upon plant genetics, environmental conditions, and maturity and processing of the corn grain at harvest [8] and can have a major impact on ration fermentability, and most likely the rumen microbiota. Lettat et al., [12] found cows fed a corn silage based TMR had an increase in total bacteria, an increase in propionate and a decrease in methane production compared to cows fed an alfalfa silage based TMR. However, information concerning the influence of corn silage based diets on the microbial ecology in the rumen of dairy cows is limited.

Information on rumen microbial dynamics in dairy cows is emerging [13-16]. Recent reports include changes in the composition of ruminal microbiota in dairy cows in association with parity [15-17], diet $[18,19]$, breed $[20,21]$, feed efficiency $[14,15,22]$, milk yield and composition $[19,23]$ and physiological status [16, 18, 24, 25]. The consensus of these reports indicates the preponderance of lineages from Bacteroidetes and Firmicutes among the rumen microbiota. However, it is not known which bacteria are relevant and in what proportions they are needed to enhance rumen fermentation of feedstuffs. In this study, our goal was to link how dietary components influence rumen bacterial populations, and how they may impact milk yield and composition in dairy cows. Here, we sampled rumen contents from primiparous and multiparous dairy cows selected from two dairy herds differing significantly in their average annual milk production. We analyzed the composition of rumen bacterial communities using Ion Torrent (PGM) sequencing and investigated their relationship with nutrition and production parameters.

\section{Methods \\ Experimental details}

This study included 85 animals of Holstein breed selected from two dairy herds in southeastern Pennsylvania, a higher producing farm (Farm 12; M305 $=12,300 \mathrm{~kg}$; $n=47$ including 24 primiparous, 23 multiparous cows (11 s, 4 third, 6 fourth, and 2 fifth lactation cows)) and a lower producing farm (Farm 9; M305 = $9700 \mathrm{~kg} ; n=38$ including 19 primiparous, 19 multiparous cows (11 s, 6 third, and 2 fourth lactation cows). Production information including milk yield $(\mathrm{kg} / \mathrm{d})$, protein (\%), and fat (\%) for experimental cows were retrieved from Dairy Record Management Systems (DRMS). We differentiated cows into high and low milk production based on their previous milk test day results for each farm and parity group. As a result, we observed at least $9 \mathrm{~kg}$ difference in daily milk yield within each parity group. The selected cows were between 79 and 179 days in milk production (DIM) (Additional file 1: Table S1) with an average of 113 and 120 days for primiparous cows and 125 and 131 days for multiparous cows in Farm 12 and Farm 9, respectively. Dairy cows that were donors of rumen fluid were maintained according to the ethics committee and IACUC standards for the University of Pennsylvania (approval \#805538).

TMR samples were collected immediately after presentation to the cows. Five samples were scooped from the dispersed feed at varying locations, combined into one sample and frozen at $-20{ }^{\circ} \mathrm{C}$. These feed samples were dried at $55{ }^{\circ} \mathrm{C}$ for $72 \mathrm{~h}$ and ground in a Wiley mill (Thomas Scientific, Swedesboro, NJ) using a 1-mm screen. DM, CP (Kjeldahl), ADF, sugars and ash were assayed according to AOAC [26]. The NDF was determined using sodium sulfite and a heat-stable $\alpha$-amylase enzyme (A3306, Sigma-Aldrich, St. Louis, MO) according to the procedure of Van Soest et al. [27]. The starch content was determined using a commercial kit (Megazyme International Ireland Ltd., Bray, Ireland) based on the enzymatic method [23]. Mineral contents were analyzed by the atomic absorption spectroscopy method and protocol of AOAC [26].

\section{Rumen sampling}

Rumen contents were sampled once from animals on each farm $2 \mathrm{~h}$ post-feeding using the stomach tube method [28]. The initial volume collected, approximately 
$200 \mathrm{~mL}$, was discarded due to possible contamination with saliva and the subsequent $250 \mathrm{ml}$ sample (planktonic phase) was obtained, transferred into $15 \mathrm{ml}$ falcon tubes and snap frozen in liquid nitrogen. The samples were then transported to the laboratory and archived at $-80{ }^{\circ} \mathrm{C}$.

\section{DNA extraction, PCR and 16S rRNA gene sequencing}

The genomic DNA was extracted from rumen samples using the PSP Spin Stool DNA Plus Kit (Invitek, Berlin, Germany). The DNA extraction method was adapted from Dollive et al. [29]. Briefly, the method involved taking $300 \mathrm{mg}$ of sample in a Lysing Matrix E tube (MP BIomedicals, Solon, OH USA) and bead beaten in $1400 \mu \mathrm{l}$ of stool stabilizer from the PSP kit to break open cell walls and release nucleic acid material. Samples were then heated at $95{ }^{\circ} \mathrm{C}$ for $15 \mathrm{~min}$, placed on ice for $1 \mathrm{~min}$, and spun down at 13,400 g for $1 \mathrm{~min}$. The supernatant was then transferred to the PSP InviAdsorb tubes and the remainder of the protocol for the PSP Spin Stool DNA Plus was followed according to the manufacturer's instructions. The genomic DNA was amplified using specific primers $27 \mathrm{~F}$ and BSR357, targeting the V1-V2 region of the $16 \mathrm{~S}$ rRNA bacterial gene. The forward primer carried the Ion Torrent trP1 (5'-CCTCTCTATGGGC AGTCGGTGAT-3') and the reverse primer carried the A adapter (5'-CCATCTCATCCCTGCGTGTCTCCGACTC AG-3'), followed by a 10-12 nucleotide (nt) samplespecific barcode sequence and a GAT barcode adapter. The PCR mix was prepared using the Accuprime Taq DNA polymerase System (Invitrogen, Carlsbad, CA).

The thermal cycling conditions involved an initial denaturing step at $95{ }^{\circ} \mathrm{C}$ for $5 \mathrm{~min}$ followed by 25 cycles (denaturing at $95{ }^{\circ} \mathrm{C}$ for $30 \mathrm{~s}$, annealing at $56{ }^{\circ} \mathrm{C}$ for $30 \mathrm{~s}$, extension at $72{ }^{\circ} \mathrm{C}$ for $90 \mathrm{~s}$ ) and, finally, an extension step at $72{ }^{\circ} \mathrm{C}$ for $8 \mathrm{~min}$ as described in Pitta et al. [18]. Amplicons of $16 \mathrm{~S}$ rRNA genes were purified using 1:1 volume of Agencourt AmPure XP beads (BeckmanCoulter, Brea, CA, USA). The purified PCR products from the rumen samples were pooled to achieve a concentration of 5-20 ng prior to sequencing in Ion Torrent (PGM) platform.

\section{Data analysis}

The 16S pyrosequence reads were analyzed using the QIIME pipeline [30], and in R 3.3.1 [31]. All sequences were quality filtered. Sequences shorter than $50 \mathrm{nt}$ and longer than $480 \mathrm{nt}$, incorrect primer sequences, and those containing one or more ambiguous bases or homopolymers longer than $5 \mathrm{nt}$ were discarded. Operational taxonomic units (OTUs) were formed at 97\% similarity using UCLUST [32]. We randomly subsampled (rarified) the resulting OTUs to 3353 sequences per sample. Representative sequences from each OTU were aligned to $16 \mathrm{~S}$ reference sequences with PyNAST [33] which were used to infer a phylogenetic tree with FastTree [34]. Taxonomic assignments within the GreenGenes taxonomy [35] were generated using the RDP Classifier version 2.2 [36].

A non-parametric permutational multivariate ANOVA (PERMANOVA) test [36], implemented in the vegan package for $\mathrm{R}$ [37] was used to test the effects of milk production, parity and farm on overall community composition, as measured by weighted UniFrac distance. To test for differences in taxon abundance, a generalized linear model (GLM) was constructed with the statistical package for $\mathrm{R}$. The model used a binomial link function and input data for the model consisted of a two-column matrix containing the number of reads assigned to the taxon (in column 1) and the number of reads assigned to other taxa (in column 2) and $p$ values were adjusted using a microbial taxonomy-wide detection rate.

The extent of relationship between bacterial communities was quantified using weighted pairwise UniFrac distances [38]. Communities with small weighted UniFrac distance are composed of phylogenetically similar organisms in similar proportions. To identify bacterial lineages that drive the clustering of microbial communities in each farm, we used the biplot function of the make_emperor.py script to plot the genus-level OTUs in PCoA (Principal Coordinate Analysis) space alongside each Farm. Spearman correlation was used to correlate physiological parameters with OTUs assigned to Succinivibrionaceae and with the abundant genera in Bacteroidetes, Firmicutes and Proteobacteria using $\mathrm{R}$ and visualized using the corrplot R package [39].

\section{Results}

\section{Dietary information}

The ingredient composition and the nutritive value of diets fed to both primiparous and multiparous dairy cows for both Farm 12 (M305 = 12,300 kg) and Farm 9 $(\mathrm{M} 305=9700 \mathrm{~kg})$ are presented in Table 1. Forage content was lower for cows on Farm 12 and averaged 49.8\% of diet DM compared to an average of $56.0 \%$ forage on Farm 9. Both farms fed corn silage as their primary forage. Farm 12 fed 77.5\% (primiparous) and 71.2\% (multiparous) of the forage as corn silage, and $22.6 \%$ (primiparous) and $25.9 \%$ (multiparous) of the forage as alfalfa silage. Additionally, $2.9 \%$ of the forage was grass hay for the multiparous cows only on Farm 12. In contrast, Farm 9 fed $85.0 \%$ (primiparous) and 81.9\% (multiparous) of the forage as corn silage and the remaining forage $15.0 \%$ (primiparous) and $18.1 \%$ (multiparous) was triticale silage. Carbohydrates fed as grains consisted of fine ground corn and wheat middlings on Farm 12 (combined, 26.2\% DM), while fine 
Table 1 Composition (\% DM) of diets fed to primiparous and multiparous cows on Farm 12 and Farm 9

\begin{tabular}{|c|c|c|c|c|}
\hline & \multicolumn{2}{|l|}{ Farm 12} & \multicolumn{2}{|l|}{ Farm 9} \\
\hline & Primiparous & Multiparous & Primiparous & Multiparous \\
\hline \multicolumn{5}{|c|}{ Ingredient composition, \%DM } \\
\hline Corn Silage $^{a}$ & 38.9 & 35.1 & 47.2 & 46.2 \\
\hline 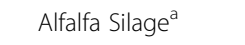 & 11.3 & 12.8 & - & - \\
\hline Triticale $e^{a}$ & - & - & 8.3 & 10.2 \\
\hline Grass Hay ${ }^{a}$ & - & 1.4 & - & - \\
\hline Corn Ground Fine & 18.2 & 20.6 & 15.2 & 14.9 \\
\hline Wheat Middlings & 8.1 & 5.4 & - & - \\
\hline Soybean Hulls & - & - & 5.5 & 5.4 \\
\hline Corn Distillers & - & - & 3.7 & 3.6 \\
\hline Citrus Pulp & - & - & 1.1 & 1.1 \\
\hline AminoPlus ${ }^{b}$ & 3.7 & 3.8 & 7.4 & 7.2 \\
\hline SoyPlus ${ }^{c}$ & 3.7 & 3.7 & - & - \\
\hline Canola Meal & 9.7 & 8.9 & - & - \\
\hline Soybean Meal & 0.4 & 1.7 & 5.5 & 5.4 \\
\hline Blood Meal & 0.5 & 0.7 & 1.0 & 1.0 \\
\hline Urea & - & - & .0 .4 & 0.4 \\
\hline Molasses & 2.1 & 1.6 & 1.3 & 1.3 \\
\hline $\begin{array}{l}\text { Energy Booster } \\
100^{d}\end{array}$ & 0.4 & 0.9 & - & - \\
\hline Megalac ${ }^{e}$ & 0.5 & 0.6 & - & - \\
\hline Pork-Vegetable Fat & - & - & 0.5 & 0.5 \\
\hline Calcium Carbonate & 0.99 & 1.01 & 1.09 & 1.11 \\
\hline $\begin{array}{l}\text { Sodium } \\
\text { Sesquicarbonate }\end{array}$ & 0.87 & 0.92 & 0.74 & 0.72 \\
\hline Sodium Chloride & 0.37 & 0.38 & 0.46 & 0.45 \\
\hline Magnesium Oxide & 0.13 & 0.13 & 0.18 & 0.18 \\
\hline Methionine, MFP & 0.07 & 0.05 & 0.11 & 0.11 \\
\hline $\begin{array}{l}\text { Methionine, } \\
\text { SmartamineM }\end{array}$ & - & 0.02 & - & - \\
\hline $\begin{array}{l}\text { Mineral-Vitamin } \\
\text { Mix }^{h}\end{array}$ & 0.06 & 0.11 & 0.22 & 0.22 \\
\hline $\begin{array}{l}\text { Rumensin } 90^{\mathrm{i}, \mathrm{j}}, \\
\mathrm{mg} / \mathrm{kg}\end{array}$ & 150.0 & 149.2 & 50.4 & 50.4 \\
\hline $\begin{array}{l}\text { Chromium . } \\
\text { propionate 4\%, }{ }^{k, l} \\
\mathrm{mg} / \mathrm{kg}\end{array}$ & 2.60 & 2.54 & 1.01 & 1.01 \\
\hline \multicolumn{5}{|c|}{ Chemical composition \%DM } \\
\hline Crude Protein & 16.5 & 16.7 & 16.2 & 15.0 \\
\hline $\begin{array}{l}\text { Soluble Protein, } \\
\% \text { CP }\end{array}$ & 31.4 & 31.2 & 32.2 & 28.4 \\
\hline $\begin{array}{l}\mathrm{RDP}^{\mathrm{m}} \text { estimated, } \\
\% \mathrm{CP}\end{array}$ & 59.1 & 56.9 & 60.2 & 59.4 \\
\hline ADF & 18.0 & 18.9 & 19.2 & 19.6 \\
\hline NDF & 28.8 & 28.3 & 30.6 & 31.3 \\
\hline$N F C^{n}$ & 44.0 & 44.6 & 42.6 & 43.1 \\
\hline Sugar & 4.5 & 4.1 & 4.3 & 5.4 \\
\hline
\end{tabular}

Table 1 Composition (\% DM) of diets fed to primiparous and multiparous cows on Farm 12 and Farm 9 (Continued)

\begin{tabular}{lllll}
\hline Starch & 27.5 & 32.1 & 26.1 & 29.2 \\
Fat & 3.8 & 3.8 & 3.4 & 3.4 \\
Ash & 6.9 & 6.7 & 7.2 & 7.2 \\
Ca & .92 & .82 & .96 & .79 \\
P & .48 & .48 & .34 & .33 \\
\hline
\end{tabular}

${ }^{\mathrm{a}}$ Forage

${ }^{\mathrm{b}}$ Heat treated soybean meal; Ag Processing Incorporated

(Omaha, Nebraska)

'Extruded soybean meal; West Central Cooperative (Ralston, lowa)

${ }^{\mathrm{d}}$ Rumen inert fat; Milk Specialties (Eden Prairie, Minnesota)

e Rumen inert fat; Arm and Hammer Animal Nutrition (Princeton, New Jersey)

f Rumen available methionine source; Novus International (Saint

Charles, Missouri)

${ }^{9}$ Rumen protected methionine; Adisseo (Alpharetta, Georgia)

${ }^{\mathrm{h}}$ Concentration (DM basis); Farm 12 Primiparous: $39 \mathrm{mg}$ of Fe/kg,

$32,795 \mathrm{mg}$ of $\mathrm{Zn} / \mathrm{kg}, 7695 \mathrm{mg}$ of $\mathrm{Cu} / \mathrm{kg}, 18,091 \mathrm{mg}$ of $\mathrm{Mn} / \mathrm{kg}, 460 \mathrm{mg}$ of $\mathrm{Se} / \mathrm{kg}, 616 \mathrm{mg}$ of

$\mathrm{Co} / \mathrm{kg}, 622 \mathrm{mg}$ of I/kg, $3203 \mathrm{KIU}$ of vitamin A/kg, $804 \mathrm{KIU}$ vitamin D/kg,

$22 \mathrm{KIU}$ vitamin E/kg; Farm 12 Multiparous: $3300 \mathrm{mg}$ of Fe/kg, 21,000 mg

of $\mathrm{Zn} / \mathrm{kg}, 5556 \mathrm{mg}$ of $\mathrm{Cu} / \mathrm{kg}, 11,118 \mathrm{mg}$ of $\mathrm{Mn} / \mathrm{kg}, 141 \mathrm{mg}$ of Se/kg,

$543 \mathrm{mg}$ of $\mathrm{Co} / \mathrm{kg}, 222 \mathrm{mg}$ of I/kg, $1032 \mathrm{KIU}$ vitamin A/kg, $258 \mathrm{KIU}$ vitamin

$\mathrm{D} / \mathrm{kg}, 10 \mathrm{KIU}$ vitamin E/kg; Farm 9 Primiparous and Multiparous

$4537 \mathrm{mg}$ of $\mathrm{Fe} / \mathrm{kg}, 19,638 \mathrm{mg}$ of $\mathrm{Zn} / \mathrm{kg}, 3724 \mathrm{mg}$ of $\mathrm{Cu} / \mathrm{kg}, 10,157 \mathrm{mg}$ of

$\mathrm{Mn} / \mathrm{kg}, 130 \mathrm{mg}$ of Se/kg, $102 \mathrm{mg}$ of Co/kg, $305 \mathrm{mg}$ of I/kg, $1067 \mathrm{KIU}$ of

vitamin A/kg, $267 \mathrm{KIU}$ vitamin D/kg, $6 \mathrm{KIU}$ vitamin E/kg;

'Elanco Animal Health (Greenfield, Indiana)

jProvided 14.6 and $15.0 \mathrm{mg}$ monensin/kg diet DM to Farm 12

primiparous and multiparous cows, respectively, and provided 14.8 and

$14.5 \mathrm{mg}$ monensin/kg diet DM to Farm 9 primiparous and multiparous

cows, respectively

${ }^{k}$ Kemin (Des Moines, lowa)

'Provided 0.25 and $0.26 \mathrm{mg}$ chromium/kg diet DM to Farm 12

primiparous and multiparous cows, respectively, and provided 0.30 and

$0.29 \mathrm{mg}$ chromium/ $\mathrm{kg}$ diet DM to Farm 9 primiparous and multiparous

cows, respectively

${ }^{m}$ Rumen degraded protein estimated using CPM-Dairy software

${ }^{n}$ Non-Fiber Carbohydrate calculated value (100-CP-NDF-Fat-Ash)

ground corn, soybean hulls, corn distillers and citrus pulp were included in the diets for Farm 9 (combined, 25.3\% DM). However, the fine ground corn averaged 15.0\% DM on Farm 9 and was higher on Farm 12 at 18.2\% DM for primiparous cows and 20.6\% DM for multiparous cows (Table 1). Analyzed TMR samples indicated the starch content of the multiparous cows on Farm 12 was the highest at $32.1 \%$, compared to the range of the other production groups of $26.1 \%$ to $29.2 \%$ dietary starch. Subsequently, NDF was higher $(31.0 \%)$ on Farm 9 than Farm $12(28.5 \%)$ and NFC was lower (42.8\%) on Farm 9 than Farm 12 (44.3\%). Sugars were similar for all production and parity groups with the exception of the multiparous cows on Farm 9 which had the highest sugar content of 5.4\% DM. Dietary fat content tended to be higher in Farm 12 due to dietary fat supplementation compared to Farm 9.

\section{Production information}

Test day records from DRMS, Raleigh, NC were extracted for cows sampled on each farm. Production 
parameters by farm and parity including milk yield $(\mathrm{kg} / \mathrm{d})$, milk fat (\%) and milk protein (\%) are presented in Table 2. A difference in milk yield of 9.5 and $18.1 \mathrm{~kg} / \mathrm{d}$ was noted between the high and low producing cows for primiparous and multiparous groups, respectively for Farm 12. A difference of 11.7 and $9.7 \mathrm{~kg} / \mathrm{d}$ was noted between high and low producing cows in the primiparous and multiparous groups, respectively for Farm 9. Milk fat (\%) was the lowest $(3.20 \%)$ in the high producing multiparous cows and was the highest $(3.86 \%)$ in the low producing multiparous cows from both Farm 9 and Farm 12, most likely associated with the higher milk yields and dilution of milk components. Milk fat (\%) was higher for the primiparous cows on Farm 9 (3.73\%) as compared to the primiparous cows on Farm 12 (3.32\%). Overall for both farms and parity groups, milk fat (\%) and protein (\%) was higher in low yielding cows compared to high yielding cows for both farms and parity groups.

\section{Sequencing information}

Approximately 660,913 reads were analyzed from 85 rumen bacterial communities, with an average of 7775 reads per sample and greater than 3353 reads per sample (Additional file 1: Table S1). Approximately 59,843 OTUs were produced by clustering at $97 \%$ sequence similarity. We randomly subsampled (rarified) OTUs to 3353 sequences per sample which produced approximately 42,223 OTUs. From these sequences, 18 bacterial phyla and 73 genera were identified.

\section{Comparison of bacterial community composition within and between herds}

The rumen bacterial communities in the planktonic phase for Farm 12 were significantly different (Adonis: $\mathrm{R}^{2}=0.16, p<0.001$; Additional file 2: Table S2; Fig. 1) from Farm 9. Bacterial communities in Farm 12 were distantly spaced and spread across the principal coordinate 1
(PC1) whereas, bacterial communities in Farm 9 formed tight clusters on PC2. PC1 was driven by Succinivibrionaceae lineages while the PC2 was driven by Prevotella, unclassified Bacteroidales, unclassified Prevotellaceae and an unclassified lineage. Within both herds, the rumen bacterial communities were significantly different by parity (PERMANOVA; $p<0.05$; Additional file 2: Table S2). However, no such differences were evident by production level within parity group in either herd, with the exception of primiparous cows in Farm 12 (Additional file 2: Table S2).

Irrespective of the herd, Bacteroidetes (75\%) and Firmicutes $(10-11 \%)$ together comprised up to $86 \%$ of the bacterial abundance. However, the mean abundance of Proteobacteria (7\% vs. 2\%) was higher in Farm 12 compared to Farm 9 (Additional file 3: Table S3). Bacteroidetes was predominated by Prevotella (48.2\%) followed by unclassified Bacteroidales and several other taxa in Farm 9. In Farm 12, Prevotella (51.8\%) was higher, while unclassified Bacteroidales and RF16 were relatively reduced and S24-7 numerically increased compared to Farm 9 (Additional file 3: Table S3). Among Firmicutes, the majority of taxa decreased in Farm 12 compared to Farm 9, with the exception of Coprococcus, unclassified Mogibacteriaceae, Pseudobutyrivibrio, Shuttleworthia and unclassified Veillonellaceae. Noticeable differences were evident in the total abundance and genera that made up Proteobacteria between both herds. In Farm 12, more than $95 \%$ of Proteobacteria was composed of Succinivibrionaceae lineages, whereas in Farm 9, Proteobacteria was comprised of several genera in addition to Succinivibrionaceae lineages (Additional file 3: Table S3).

Differences in the individual bacterial populations are presented for the high and low yielding cows within each parity level in both herds (Table 3). In the high yielding primiparous cows of Farm 12, Prevotella from Bacteroidetes was significantly higher compared to the low yielding primiparous cows. The contribution from Firmicutes decreased while that of Proteobacteria

Table 2 Mean with SD of production parameters in high and low yielding cows by parity and farm

\begin{tabular}{|c|c|c|c|c|c|c|c|c|}
\hline & \multicolumn{4}{|l|}{ Farm 12} & \multicolumn{4}{|l|}{ Farm 9} \\
\hline & \multicolumn{2}{|c|}{ Primiparous cows } & \multicolumn{2}{|c|}{ Multiparous cows } & \multicolumn{2}{|c|}{ Primiparous cows } & \multicolumn{2}{|c|}{ Multiparous cows } \\
\hline & High & Low & High & Low & High & Low & High & Low \\
\hline & $(n=12)$ & $(n=12)$ & $(n=12)$ & $(n=11)$ & $(n=10)$ & $(n=9)$ & $(n=9)$ & $(n=10)$ \\
\hline Days in milk & 116 & 109 & 125 & 125 & 128 & 113 & 130 & 132 \\
\hline \multirow[t]{2}{*}{ Milk yield $(\mathrm{kg} / \mathrm{d})$} & 48.1 & 38.6 & 70.7 & 52.6 & 37.2 & 25.5 & 41.8 & 32.1 \\
\hline & \pm 1.3 & \pm 1.2 & \pm 4.3 & \pm 3.3 & \pm 7.1 & \pm 2.7 & \pm 3.4 & \pm 3.4 \\
\hline \multirow[t]{2}{*}{ Fat (\%) } & 3.31 & 3.34 & 3.20 & 3.86 & 3.64 & 3.83 & 3.19 & 3.86 \\
\hline & \pm 0.57 & \pm 0.61 & \pm 1.25 & \pm 0.90 & \pm 0.36 & \pm 0.62 & \pm 0.48 & \pm 0.67 \\
\hline \multirow[t]{2}{*}{ Protein (\%) } & 2.85 & 2.94 & 2.86 & 3.23 & 2.91 & 2.94 & 2.87 & 3.03 \\
\hline & \pm 0.22 & \pm 0.20 & \pm 0.27 & \pm 0.28 & \pm 0.22 & \pm 0.30 & \pm 0.23 & \pm 0.23 \\
\hline
\end{tabular}




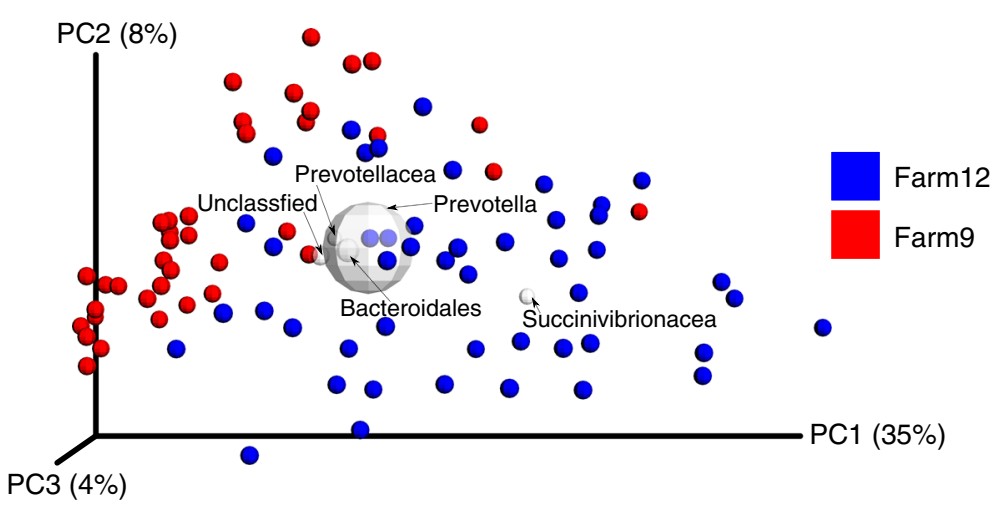

Fig. 1 Biplot of weighted UniFrac beta diversity plot, labels for the most 5 abundant genus-level taxa added. The size of the sphere for each taxon is proportional to the mean relative abundance of that taxon across all samples. This plot is created by the QIIME command make_emperor.py

increased in the high yielding primiparous cows compared to the low yielding primiparous cows. Members of Succinivibrionaceae lineages were almost doubled $(p<0.05)$ in high versus low yielders in the primiparous cows.

In the high yielding multiparous cows of Farm 12, the contribution from Bacteroidetes was lower compared to the low yielding multiparous cows, while several Firmicutes lineages increased, unlike what was observed in the primiparous cows. Distinct differences in Proteobacteria populations were not evident between high and low yielding multiparous cows, except for Succinivibrionaceae lineages which were increased in the high yielders $(p<0.05)$. No evident patterns were observed between high and low yielding cows in Farm 9.

\section{Diversity of Succinivibrionaceae}

As Succinivibrionaceae lineages were abundant in Farm 12 and were found to be higher $(p<0.05)$ in high yielding primiparous and multiparous cows, we performed additional analysis on the sequences that were annotated to Succinivibrionaceae lineages. Across all samples, we identified a total of 326 OTUs that were assigned to this bacterial family (Fig. 2). Of the 326 OTUs, 143 OTUs were common to both farms. About 141 were unique to Farm 12 and 42 OTUs were identified only in Farm 9. In Farm 12, OTU45762 was found in all samples and comprised $35 \%$ of Succinivibrionaceae abundance. In contrast, this OTU was not detected in a majority of samples in Farm 9. Instead OTU16670 was found to be the most abundant OTU in Farm 9, but was less than 5\% in Farm 12. Similar patterns were observed for a majority of Succinivibrionaceae OTUs, where the OTUs that were abundant in Farm 12 contributed only a small portion in Farm 9 and vice versa. These results indicate the diversity among Succinivibrionaceae OTUs in Farm 12 is different compared to that of Farm 9.
Correlations between rumen bacterial populations and production traits

To investigate the relationship between bacterial populations and production traits, we performed a Spearman correlation test for the most abundant taxa within Bacteroidetes, Firmicutes and Proteobacteria (Fig. 3). In general, bacterial taxa that were positively correlated with milk yield, showed negative correlations with fat and protein content in milk. Prevotella and S24-7 from Bacteroidetes, and Succinivibrionaceae lineages from Proteobacteria were positively correlated with milk yield. All taxa except Christensenellaceae, Coprococcus, Erysipelotrichaceae, Lachnospiraceae, Shuttleworthia and Veillonellaceae lineages from Firmicutes (Fig. 3) showed positive correlations with milk fat and protein content.

As the diversity of Succinivibrionaceae was different between farms, we performed correlations between the most abundant Succinivibrionaceae OTUs and production variables in this study (Additional file 4: Figure S1). The OTUs selected for this analysis were OTUs 45,762, $46,605,22,052,35,471,14,464,58,055,7873,20,365$, and 11,472) from Farm 12 and the only abundant OTU (16670) from Farm 9. Interestingly, we found that all Succinivibrionaceae OTUs from Farm 12 were found to be positively correlated to milk yield and negatively correlated with fat and protein content, whereas OTU16670 from Farm 9 showed the opposite trend.

\section{Discussion}

In the Pennsylvania dairy sector, average annual milk production per cow (M305) is about $10,000 \mathrm{~kg}$. In this study, Farm $12(\mathrm{M} 305=12,300 \mathrm{~kg})$ represented the top $5 \%$ of Pennsylvania dairy herds and Farm 9 (M305 = $9700 \mathrm{~kg}$ ) represented the average dairy herd in Pennsylvania [40]. There are many sources to account for variation in milk yield between dairy farms. Genetics accounts for approximately $25 \%$ of the variation [41] and management factors, 
Table 3: Mean abundance (\%) and SEM of bacterial taxa (identified to the genus level) between low and high yielding cows within parity in Farm 12 and Farm 9

\begin{tabular}{|c|c|c|c|c|c|c|c|}
\hline \multirow[b]{2}{*}{ Taxa } & \multirow[b]{2}{*}{ Herd } & \multicolumn{3}{|c|}{ Primiparous cows } & \multicolumn{3}{|c|}{ Multiparous cows } \\
\hline & & Low & High & $P$-value ${ }^{\ddagger}$ & Low & High & $P$-value \\
\hline \multicolumn{8}{|l|}{ Bacteroidetes (Phylum) } \\
\hline \multirow{2}{*}{$\begin{array}{l}\text { Paraprevotellaceae } \\
\text { (family) }\end{array}$} & Farm12 & $0.70 \pm 0.05$ & $0.57 \pm 0.08$ & * & $0.95 \pm 0.06$ & $0.82 \pm 0.05$ & \\
\hline & Farm9 & $0.85 \pm 0.10$ & $0.80 \pm 0.05$ & & $0.69 \pm 0.06$ & $0.58 \pm 0.05$ & \\
\hline \multirow{2}{*}{$\begin{array}{l}\text { Bacteroidales } \\
\text { (order) }\end{array}$} & Farm12 & $11.54 \pm 0.29$ & $10.32 \pm 0.30$ & $* * *$ & $10.54 \pm 0.59$ & $9.87 \pm 0.32$ & * \\
\hline & Farm9 & $11.28 \pm 0.52$ & $12.03 \pm 0.59$ & $* *$ & $12.43 \pm 0.43$ & $11.89 \pm 0.38$ & \\
\hline \multirow[t]{2}{*}{ BF311 } & Farm12 & $0.06 \pm 0.01$ & $0.08 \pm 0.02$ & & $0.10 \pm 0.04$ & $0.04 \pm 0.01$ & * \\
\hline & Farm9 & $0.10 \pm 0.03$ & $0.18 \pm 0.03$ & * & $0.16 \pm 0.03$ & $0.17 \pm 0.03$ & \\
\hline \multirow[t]{2}{*}{ CF231 } & Farm12 & $0.70 \pm 0.07$ & $0.61 \pm 0.07$ & & $0.84 \pm 0.06$ & $0.73 \pm 0.04$ & \\
\hline & Farm9 & $1.16 \pm 0.11$ & $1.27 \pm 0.12$ & & $1.24 \pm 0.08$ & $1.06 \pm 0.09$ & \\
\hline \multirow[t]{2}{*}{ Prevotella } & Farm12 & $50.35 \pm 1.71$ & $53.39 \pm 1.29$ & $* * *$ & $51.51 \pm 1.80$ & $52.05 \pm 1.08$ & \\
\hline & Farm9 & $49.55 \pm 2.72$ & $45.05 \pm 1.77$ & $* * *$ & $47.60 \pm 2.13$ & $50.59 \pm 1.74$ & $* * *$ \\
\hline \multirow{2}{*}{$\begin{array}{l}\text { Prevotellaceae } \\
\text { (family) }\end{array}$} & Farm12 & $4.16 \pm 0.13$ & $4.22 \pm 0.27$ & & $3.45 \pm 0.25$ & $3.19 \pm 0.16$ & \\
\hline & Farm9 & $4.30 \pm 0.30$ & $4.36 \pm 0.21$ & & $5.13 \pm 0.27$ & $4.96 \pm 0.20$ & \\
\hline \multirow{2}{*}{$\begin{array}{l}\text { RF16 } \\
\text { (family) }\end{array}$} & Farm12 & $1.14 \pm 0.20$ & $0.93 \pm 0.10$ & $* *$ & $1.07 \pm 0.12$ & $1.09 \pm 0.09$ & \\
\hline & Farm9 & $2.03 \pm 0.28$ & $3.38 \pm 0.47$ & $* * *$ & $1.51 \pm 0.24$ & $1.39 \pm 0.43$ & \\
\hline \multirow{2}{*}{$\begin{array}{l}\text { S24-7 } \\
\text { (family) }\end{array}$} & Farm12 & $3.04 \pm 0.34$ & $2.34 \pm 0.11$ & $* * *$ & $3.25 \pm 0.36$ & $2.99 \pm 0.49$ & \\
\hline & Farm9 & $2.21 \pm 0.42$ & $2.48 \pm 0.27$ & $*$ & $1.70 \pm 0.28$ & $1.93 \pm 0.31$ & \\
\hline \multirow[t]{2}{*}{ YRC22 } & Farm12 & $0.52 \pm 0.06$ & $0.54 \pm 0.06$ & & $0.54 \pm 0.05$ & $0.54 \pm 0.05$ & \\
\hline & Farm9 & $0.63 \pm 0.05$ & $0.68 \pm 0.06$ & & $0.85 \pm 0.07$ & $0.60 \pm 0.06$ & $* * *$ \\
\hline \multicolumn{8}{|l|}{ Firmicutes (Phylum) } \\
\hline \multirow{2}{*}{$\begin{array}{l}\text { Mogibacteriaceae } \\
\text { (family) }\end{array}$} & Farm12 & $0.19 \pm 0.03$ & $0.14 \pm 0.02$ & & $0.27 \pm 0.04$ & $0.18 \pm 0.03$ & \\
\hline & Farm9 & $0.16 \pm 0.05$ & $0.22 \pm 0.03$ & & $0.11 \pm 0.01$ & $0.11 \pm 0.02$ & \\
\hline \multirow[t]{2}{*}{ Anaerostipes } & Farm12 & $\mathrm{NF}$ & $\mathrm{NF}$ & & $0.04 \pm 0.01$ & $0.07 \pm 0.01$ & \\
\hline & Farm9 & $0.06 \pm 0.02$ & $0.09 \pm 0.02$ & & NF & NF & \\
\hline \multirow[t]{2}{*}{ Anaerovibrio } & Farm12 & $\mathrm{NF}$ & $\mathrm{NF}$ & & $0.06 \pm 0.02$ & $0.04 \pm 0.01$ & \\
\hline & Farm9 & $0.04 \pm 0.01$ & $0.06 \pm 0.01$ & & $0.09 \pm 0.02$ & $0.08 \pm 0.02$ & \\
\hline \multirow[t]{2}{*}{ Asteroleplasma } & Farm12 & $0.10 \pm 0.02$ & $0.09 \pm 0.03$ & & $0.07 \pm 0.02$ & $0.10 \pm 0.02$ & \\
\hline & Farm9 & $0.16 \pm 0.04$ & $0.10 \pm 0.02$ & & $0.18 \pm 0.03$ & $0.19 \pm 0.03$ & \\
\hline \multirow[t]{2}{*}{ Butyrivibrio } & Farm12 & $0.24 \pm 0.04$ & $0.09 \pm 0.02$ & $* * *$ & $0.26 \pm 0.05$ & $0.20 \pm 0.03$ & \\
\hline & Farm9 & $0.36 \pm 0.06$ & $0.24 \pm 0.04$ & & $0.31 \pm 0.05$ & $0.36 \pm 0.10$ & \\
\hline \multirow{2}{*}{$\begin{array}{l}\text { Christensenellaceae } \\
\text { (family) }\end{array}$} & Farm12 & $0.09 \pm 0.02$ & $0.06 \pm 0.01$ & & $0.07 \pm 0.02$ & $0.05 \pm 0.01$ & \\
\hline & Farm9 & $0.08 \pm 0.02$ & $0.10 \pm 0.02$ & & $0.08 \pm 0.02$ & $0.12 \pm 0.02$ & \\
\hline \multirow{2}{*}{$\begin{array}{l}\text { Clostridiales } \\
\text { (order) }\end{array}$} & Farm12 & $2.70 \pm 0.20$ & $1.89 \pm 0.14$ & $* * *$ & $3.33 \pm 0.37$ & $3.25 \pm 0.38$ & \\
\hline & Farm9 & $3.07 \pm 0.35$ & $3.05 \pm 0.16$ & & $3.36 \pm 0.39$ & $2.98 \pm 0.27$ & \\
\hline \multirow[t]{2}{*}{ Coprococcus } & Farm12 & $0.07 \pm 0.01$ & $0.04 \pm 0.01$ & & $0.18 \pm 0.05$ & $0.13 \pm 0.02$ & \\
\hline & Farm9 & $0.06 \pm 0.01$ & $0.07 \pm 0.02$ & & $0.05 \pm 0.01$ & $0.05 \pm 0.01$ & \\
\hline Erysipelotrichaceae & Farm12 & NF & NF & & $0.03 \pm 0.01$ & $0.03 \pm 0.01$ & \\
\hline & Farm9 & $0.06 \pm 0.01$ & $0.05 \pm 0.02$ & & NF & NF & \\
\hline Lachnospiraceae & Farm12 & $1.31 \pm 0.10$ & $1.09 \pm 0.12$ & * & $1.53 \pm 0.15$ & $1.84 \pm 0.15$ & $* *$ \\
\hline & Farm9 & $1.48 \pm 0.21$ & $1.41 \pm 0.10$ & & $1.56 \pm 0.27$ & $1.46 \pm 0.15$ & \\
\hline Moryella & Farm12 & $0.06 \pm 0.02$ & $0.05 \pm 0.01$ & & $0.13 \pm 0.02$ & $0.10 \pm 0.03$ & \\
\hline & Farm9 & $0.13 \pm 0.04$ & $0.12 \pm 0.02$ & & NF & NF & \\
\hline
\end{tabular}


Table 3: Mean abundance (\%) and SEM of bacterial taxa (identified to the genus level) between low and high yielding cows within parity in Farm 12 and Farm 9 (Continued)

\begin{tabular}{|c|c|c|c|c|c|c|c|}
\hline \multirow[t]{2}{*}{$p-75-a 5$} & Farm12 & NF & NF & & NF & NF & \\
\hline & Farm9 & $0.05 \pm 0.01$ & $0.06 \pm 0.01$ & & $0.06 \pm 0.01$ & $0.07 \pm 0.02$ & \\
\hline \multirow[t]{2}{*}{ Pseudobutyrivibrio } & Farm12 & $0.07 \pm 0.02$ & $0.05 \pm 0.01$ & & $0.10 \pm 0.03$ & $0.13 \pm 0.03$ & \\
\hline & Farm9 & $0.08 \pm 0.02$ & $0.05 \pm 0.01$ & & $0.06 \pm 0.02$ & $0.07 \pm 0.02$ & \\
\hline \multirow[t]{2}{*}{ RFN2O } & Farm12 & $0.53 \pm 0.06$ & $0.42 \pm 0.05$ & * & $0.49 \pm 0.06$ & $0.38 \pm 0.04$ & \\
\hline & Farm9 & $0.79 \pm 0.07$ & $0.87 \pm 0.09$ & & $0.62 \pm 0.07$ & $0.65 \pm 0.05$ & \\
\hline \multirow{2}{*}{$\begin{array}{l}\text { Ruminococcaceae } \\
\text { (family) }\end{array}$} & Farm12 & $1.40 \pm 0.14$ & $0.91 \pm 0.13$ & $* * *$ & $1.43 \pm 0.17$ & $1.15 \pm 0.12$ & $* *$ \\
\hline & Farm9 & $1.51 \pm 0.25$ & $1.56 \pm 0.17$ & & $1.24 \pm 0.16$ & $1.24 \pm 0.12$ & \\
\hline \multirow[t]{2}{*}{ Ruminococcus } & Farm12 & $0.89 \pm 0.13$ & $0.56 \pm 0.10$ & $* * *$ & $0.93 \pm 0.09$ & $0.91 \pm 0.11$ & \\
\hline & Farm9 & $1.25 \pm 0.23$ & $1.17 \pm 0.11$ & & $1.08 \pm 0.26$ & $0.99 \pm 0.15$ & \\
\hline \multirow[t]{2}{*}{ Schwartzia } & Farm12 & $0.06 \pm 0.01$ & $0.07 \pm 0.02$ & & $0.07 \pm 0.01$ & $0.07 \pm 0.01$ & \\
\hline & Farm9 & NF & NF & & NF & NF & \\
\hline \multirow[t]{2}{*}{ Selenomonas } & Farm12 & $0.14 \pm 0.02$ & $0.08 \pm 0.02$ & * & $0.17 \pm 0.03$ & $0.18 \pm 0.03$ & \\
\hline & Farm9 & $0.15 \pm 0.03$ & $0.09 \pm 0.03$ & & $0.20 \pm 0.06$ & $0.18 \pm 0.03$ & \\
\hline \multirow[t]{2}{*}{ Shuttleworthia } & Farm12 & $0.08 \pm 0.01$ & $0.06 \pm 0.01$ & & $0.08 \pm 0.02$ & $0.10 \pm 0.02$ & \\
\hline & Farm9 & NF & NF & & $0.05 \pm 0.01$ & $0.04 \pm 0.01$ & \\
\hline \multirow[t]{2}{*}{ Succiniclasticum } & Farm12 & $0.17 \pm 0.02$ & $0.10 \pm 0.02$ & * & $0.20 \pm 0.03$ & $0.18 \pm 0.03$ & \\
\hline & Farm9 & $0.20 \pm 0.02$ & $0.13 \pm 0.03$ & & $0.13 \pm 0.02$ & $0.13 \pm 0.03$ & \\
\hline \multirow{2}{*}{$\begin{array}{l}\text { Veillonellaceae } \\
\text { (family) }\end{array}$} & Farm12 & $0.66 \pm 0.08$ & $0.63 \pm 0.08$ & & $0.70 \pm 0.10$ & $0.70 \pm 0.06$ & \\
\hline & Farm9 & $0.55 \pm 0.04$ & $0.41 \pm 0.05$ & & $0.55 \pm 0.08$ & $0.55 \pm 0.08$ & \\
\hline \multicolumn{8}{|l|}{ Proteobacteria (Phylum) } \\
\hline \multirow{2}{*}{$\begin{array}{l}\text { Alphaproteobacteria } \\
\text { (class) }\end{array}$} & Farm12 & $0.07 \pm 0.01$ & $0.06 \pm 0.01$ & & $0.05 \pm 0.02$ & $0.08 \pm 0.01$ & \\
\hline & Farm9 & $0.14 \pm 0.04$ & $0.15 \pm 0.03$ & & $0.08 \pm 0.03$ & $0.07 \pm 0.02$ & \\
\hline \multirow{2}{*}{$\begin{array}{l}\text { Deltaproteobacteria } \\
\text { (class) }\end{array}$} & Farm12 & NF & NF & & NF & NF & \\
\hline & Farm9 & $0.03 \pm 0.01$ & $0.05 \pm 0.01$ & & $0.03 \pm 0.01$ & $0.05 \pm 0.01$ & \\
\hline \multirow{2}{*}{$\begin{array}{l}R F 32 \\
\text { (order) }\end{array}$} & Farm12 & $0.11 \pm 0.02$ & $0.11 \pm 0.02$ & & $0.15 \pm 0.03$ & $0.09 \pm 0.02$ & * \\
\hline & Farm9 & $0.16 \pm 0.05$ & $0.18 \pm 0.02$ & & $0.11 \pm 0.03$ & $0.11 \pm 0.03$ & \\
\hline \multirow[t]{2}{*}{ Ruminobacter } & Farm12 & NF & NF & & NF & NF & \\
\hline & Farm9 & $0.05 \pm 0.02$ & $0.09 \pm 0.02$ & & NF & NF & \\
\hline \multirow{2}{*}{$\begin{array}{l}\text { Succinivibrionaceae } \\
\text { (family) }\end{array}$} & Farm12 & $4.48 \pm 0.76$ & $8.11 \pm 2.05$ & $* * *$ & $5.92 \pm 1.80$ & $8.02 \pm 1.45$ & $* * *$ \\
\hline & Farm9 & $1.41 \pm 0.28$ & $2.68 \pm 0.92$ & $* * *$ & $0.85 \pm 0.32$ & $0.66 \pm 0.30$ & $*$ \\
\hline
\end{tabular}

${ }^{\ddagger} P$-value comparing bacterial abundance of high and low milk production within parity The magnitude of the $P$-value $\left({ }^{* * *} P<0.001\right.$; $\left.{ }^{* *} P<0.01 ;{ }^{*} P<0.05\right)$ NF Not found

including cow comfort, milking frequency, ration formulation and feeding management contribute to the remaining $75 \%$ [42]. While animal genetics, nutrition and management can greatly influence milk production differences among herds, our objective was to investigate how diet impacts microbiota and how rumen bacterial community compositions differ in dairy cows with varying milk production. To accomplish our goal and to obtain large numbers of cows varying in parity and production, we selected two commercial dairy herds, knowing that we would not be able to control the many aspects of herd variation that influence milk yield. We used the stomach tube method for rumen sample collection, realizing only the planktonic associated microbiota is typically retrieved, however this approach allowed us to sample large groups of cows across herds. To this end, we sampled rumen fluid from higher and lower yielding dairy cows across two farms in Pennsylvania and investigated the bacterial diversity using Ion Torrent (PGM) sequencing. The salient findings from this study are that each farm had a unique bacterial profile and the rumen bacterial composition differed substantially between the herds. The inter-herd differences were much greater than intra-herd differences in their rumen bacterial composition, which was not surprising due to 


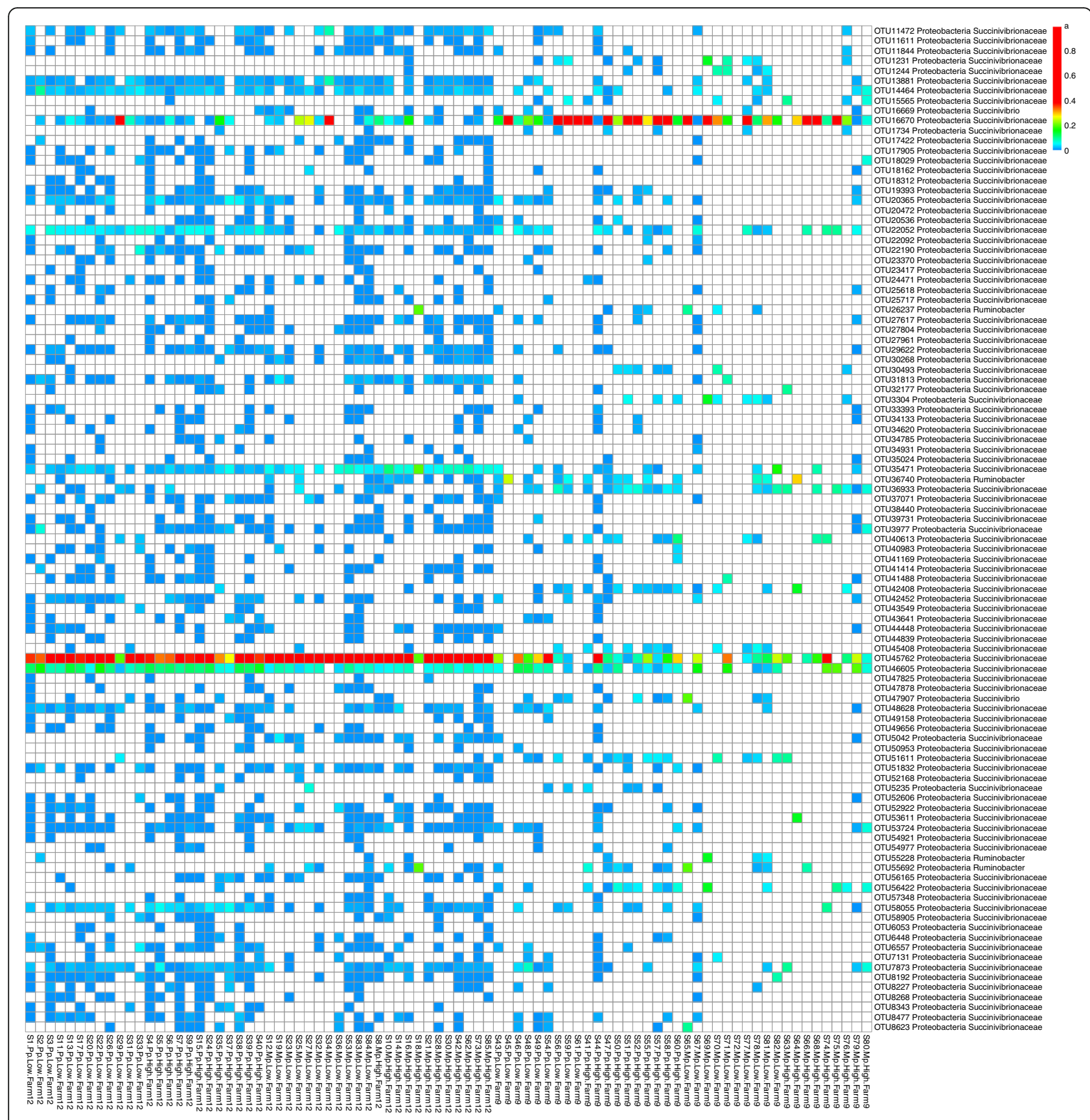

Fig. 2 Heatmap showing the distribution of OTUs assigned to Succinivibrionaceae family in dairy cows in Farm 12 and Farm 9

large differences in dietary composition between the herds. This study identified the presence of specialist rumen bacteria including Succinivibrionaceae lineages, Coprococcus and S24-7, which were associated with higher milk yields in Farm 12.

\section{Rumen bacterial community composition}

Across both farms in this study, Bacteroidetes, mostly comprised of Prevotella, Bacteroidales, and Prevotellaceae lineage, and Firmicutes, mainly comprised of
Clostridiales, Lachnospiraceae, and Ruminococcaceae lineages constituted $75 \%$ and 10 to $11 \%$ of the rumen bacterial composition, respectively. The abundance of Bacteroidetes and Firmicutes in the rumen of dairy cows is a common finding reported by several authors [14-16]. However, the proportion of Bacteroidetes observed in this study was much higher compared to the above reports, but similar to our previous findings $[17,18]$. Differences among reports can be attributed to differences in dietary composition, sampling times 


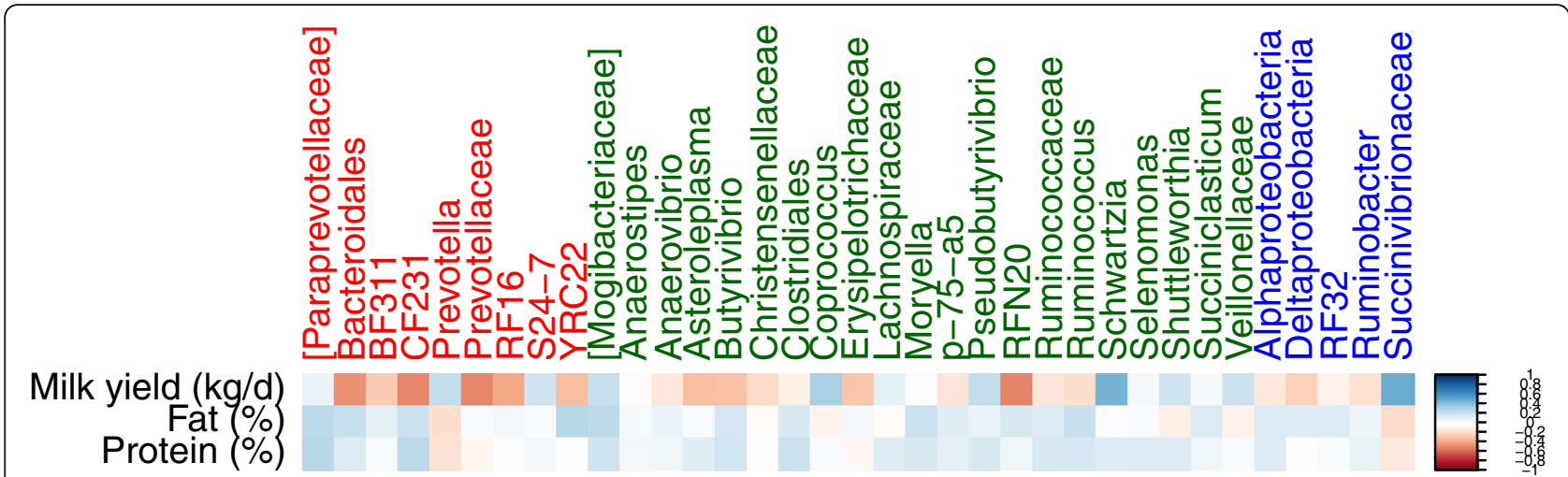

Fig. 3 Correlation between production variables and abundant ruminal bacterial genera. The scale colors denote whether the correlation is positive (closer to 1, blue squares) or negative (closer to -1 , red squares) between the taxa and the production parameters. The taxa colors red, dark green and blue denotes the genus of Bacteroidetes, Firmicutes and Proteobacteria respectively

and methodologies employed in rumen bacterial diversity analysis [43].

Previous reports $[15,16]$ indicate Proteobacteria accounts for a very small proportion (1-5\%) of the rumen bacterial population. Compared to these reports $[15,16]$, the contribution from Proteobacteria in Farm 12 was higher than expected at 7\%, but on the lower end of reported ranges in Farm 9, where Proteobacteria comprised only $2 \%$. Notably, in Farm 12, Succinivibrionaceae lineages represented $97 \%$ of the Proteobacteria. The proportions of Bacteroidetes, Firmicutes and Proteobacteria in dairy cows from Farm 9 were similar to our earlier reports from the same herd $[17,18]$. This consistency in findings on Farm 9 suggests that the rumen bacterial profiles remain fairly stable for a dairy herd under similar management and dietary regimen.

\section{Linking diets and rumen bacterial communities}

The feed ingredients used in the TMR for Farm 9 and Farm 12 were different. Differences in dietary composition were well reflected in the inter-herd differences in rumen bacterial community composition, which may have contributed to differences in rumen digestion and influenced milk yields between herds. The rumen bacterial communities in Farm 12 were diverse and were driven by Prevotella, Bacteroidales, unclassified Prevotellaceae and Succinivibrionaceae, while in Farm 9 there was little variation within rumen bacterial communities, driven mostly by Prevotella, Bacteroidales and unclassified Prevotellaceae.

Rumen bacteria with a known function such as S24-7 for butyrate production [44], Coprococcus for propionate and butyrate production [22] and Succinivibrionaceae for succinate production [45] were found to be greater in abundance in Farm 12. Notably, Schwartzia, a genus from Firmicutes reported to utilize only succinic acid [46] was detected only in Farm 12. These bacteria with specific functions were in greater relative abundance on
Farm 12 and observed to be positively correlated with milk production. Recently it was shown that both Coprococcus and Succinivibrionaceae were positively correlated with gross feed efficiency in dairy cows [22]. Similarly, Succinivibrionaceae also compete with methanogens for hydrogen required to make succinate, a precursor for propionate [47]. Succinivibrionaceae has roles in mitigating methane production and in producing propionate to supply energy to the host for tissue metabolism [45]. One plausible mechanism for increased milk yield in Farm 12 could be Succinivibrionaceae converting succinate to propionate which is metabolized in the liver to glucose, a precursor for lactose synthesis regulating milk volume [48].

It is well known that the diet fed to a ruminant is a major driver in determining the composition of microbial communities in the rumen [19, 41, 42]. In this study we attribute the inter-herd differences in rumen bacterial composition to dietary factors, particularly forage \%DM, forage type, and amount of corn grain and types of byproducts fed on the farms. Forage was fed at a higher \%DM on Farm 9 (56\%), however, corn silage was the major forage fed on both farms. The starch in properly ensiled corn silage is generally readily available in the rumen due to the moisture and softness of the kernel. However, starch availability in the rumen is also dependent upon maturity and processing of the corn kernel at harvest. Starch from corn silage on Farm 12 may have been more available to rumen microbes due to the use of more sophisticated self-propelled harvesting and kernel processing equipment, allowing kernels to be pulverized completely. Farm 9 used a pull type forage harvester and built-in processor producing kernels that were only knicked or broken into small visible pieces, possibly limiting rumen available starch. In addition to corn silage, Farm 12 fed alfalfa silage to complement their forage base. Alfalfa silage, when fed to steers, 
showed an increased abundance of Bacteroidetes and Proteobacteria as compared to Sainfoin silage [49]. Further, in experiments that involved feeding a combination of corn silage ( $33 \% \mathrm{DM})$ and alfalfa silage ( $25 \% \mathrm{DM})$, rumen Succinovibrionaceae was detected at $4 \%$ in the liquid and 6\% in the solid fraction [15]. When corn silage comprised 60\% DM and alfalfa silage 9\% DM, rumen Succinivibrionaceae was reported at $4 \%$ in dairy cows [15]. Similar to these findings, the combination of corn silage and alfalfa silage fed on Farm 12 may have contributed to the higher abundance of rumen Succinivibrionaceae at $4-8 \%$. Succinivibrionaceae OTUs were also more diverse and positively correlated with milk yield in Farm 12 compared to Farm 9, where Succinivibrionaceae OTUs associated with milk production were not detected. Triticale (a hybrid of rye and wheat) silage was fed with corn silage on Farm 9. Triticale is a grass forage and by nature has higher NDF values than legumes harvested at the same relative maturities. Triticale silage had higher NDF concentrations compared to barley and oat silages and resulted in higher molar proportions of acetate and lower molar proportions of butyrate in the rumen compared to barley silage [50]. Congruent to these findings, the NDF concentration on Farm 9 (31.0\%) was relatively higher compared to Farm $12(28.5 \%)$. Higher forage \%DM and relatively higher NDF content may have contributed to the relative higher concentrations of Fibrobacter and Firmicutes [18, 51, 52] on farm 9 compared to farm 12. Further studies are required to investigate the extent of fermentability of corn silage alone and in combination with other legume and cereal silages on the rumen microbial populations, as these forages form a major component (50 to 70\%) in lactating dairy cow diets [53]. Such studies will give insight into dietary-microbial interactions to enhance milk yields in dairy cows.

In addition to forages, non-forage fiber byproducts were fed on both farms. Wheat middlings were the only byproduct fed on Farm 12. In general, wheat middlings contain the highest concentration of starch (19\%) compared to many other common byproducts fed to dairy cows. Farm 9 fed corn distillers (12\% starch), soyhulls, and citrus pulp, both containing less than $5 \%$ starch. In addition, the mean proportion of ground corn (19.4\%) in Farm 12 TMR was about $4.3 \%$ units greater than that of Farm 9 (15.1\%), suggesting increased rumen starch availability on Farm 12. We speculate an increase in rumen Succinivibrionaceae may be associated with greater starch availability in the rumen of high yielding dairy cows in Farm 12. High-grain diets appear to favor the growth of these bacterial populations [45, 54], which agrees with the findings of this study, where corn grain was fed in higher amounts on Farm 12. In addition to higher concentrations of starch, processing of grain has a major impact on the rumen availability of starch, and thus can influence the populations of Succinivibrionaceae in the rumen as revealed by the findings of (Shipp et al, Effects of corn processing method and dietary inclusion of wet distillers grains with soluble on rumen microbial dynamics in finishing steers Ginger, submitted), where the authors observed that Succinivibrionaceae was doubled when finishing beef cattle were fed steam flaked corn compared to dry rolled corn. Again, supporting the increase in rumen Succinivibrionaceae may be associated with greater starch availability in the rumen of high yielding dairy cows in Farm 12. The highest dietary starch concentration in this study (32.1\%) was in the multiparous cows on Farm 12, which was also the group with the highest level of milk production. Additionally, DMI increases with the amount of milk produced $[3,53]$, suggesting cows on Farm 12 ate more TMR DM compared to Farm 9, thus consuming greater amounts of dietary starch to enhance the production of VFA and microbial protein for milk production.

Identification of specialized rumen bacteria is needed for improving productivity of dairy cows [55], and the findings of Pope et al. [45] have created renewed interest in Succinivibrionaceae among the scientific community. Several papers have been published recently concerning this bacterial population $[47,56,57]$. The abundance of Succinivibrionaceae lineages in Farm 12 is noteworthy, particularly the greater abundance of this bacterial population in the high yielding cows in both parity groups. Identification of dietary factors including forage varieties, starch concentration and processing methods can favor the growth of Succinivibrionaceae and other specialist bacteria in the rumen that may positively impact digestion and metabolism of feed substrates to ultimately improve milk production in dairy cows.

\section{Conclusion}

This study compared the rumen bacterial populations between two dairy herds differing by $2600 \mathrm{~kg} / \mathrm{cow}$ in annual milk production. It can be concluded that withinherd differences are small compared to between-herd differences in the composition of rumen bacterial populations. In this study we attribute inter-herd differences in rumen bacterial composition to dietary factors, particularly forage \%DM, forage type, and amount of corn grain and byproducts fed on the farms. The distinct abundance of Succinivibrionaceae lineages in Farm 12 was enlightening, particularly the greater abundance of this bacterial population in the high yielding cows in both parity groups. Our study suggests the growth of Succinivibrionaceae linages may have been associated with greater starch availability in the rumen, where corn grain was fed in higher amounts on Farm 12 and corn silage starch may have also been more readily available 
due to better kernel processing. Controlled studies are needed to more fully understand the impact of both NDF and starch components in corn silage and other forages on rumen microbial populations. Specific selection of NFC sources including starch, sugars, and nonforage fiber sources to compliment forage inputs will give additional insight into dietary microbial interactions important in improving milk yields on dairy farms. Identification of specialized rumen bacteria in dairy cows capable of improving nutrient utilization and feed conversion are needed to continually improve milk production and feed efficiency on dairy farms. Interactions between diet, rumen microbial and fermentation dynamics, and milk yield and components will expand our knowledge to benefit the dairy industry at large.

\section{Additional files}

Additional file 1: Table S1. Sequencing details and production data for samples from cows on Farms 12 and 9. (DOCX $30 \mathrm{~kb}$ )

Additional file 2: Table S2. Multivariate permutational analysis (PERMANOVA) for differences in bacterial communities with regard to milk production and parity, both within and between Farm 12 and

Farm 9. (DOCX $15 \mathrm{~kb}$ )

Additional file 3: Table S3. Bacterial abundance (\%) at phylum, family and genus level for low and high yielding cows within parity in Farm 12 and Farm 9. (DOCX 53 kb)

Additional file 4: Figure S1. Spearman correlation between milk production parameters and most abundant Succinivibrionaceae OTUs across rumen samples. The scale colors denote whether the correlation is positive (closer to 1, blue squares) or negative (closer to -1 , red squares) between the Succinivibrionaceae OTU and the milk production parameters. (PDF $12 \mathrm{~kb}$ )

\section{Abbreviations}

DIM: Days in milk production; DM: Dry matter; DMI: Dry matter intake DRMS: Dairy Record Management Systems; FC: Fiber carbohydrates; GLM: generalized linear model; NDF: Neutral detergent fiber; NFC: Non-fiber carbohydrate; OTU: Operational taxonomic unit; PGM: Personnel genome machine; QIIME: Quantitative insights into microbial ecology; TMR: Total mixed rations

\section{Acknowledgments}

We are thankful to the Biomedical Research Core Facilities, University of Pennsylvania, for sequencing services.

\section{Funding}

This research received no specific grant from any funding agency in the public, commercial, or not-for-profit sectors.

\section{Availability of data and materials}

The raw sequence data, corresponding metadata, quality filtered reads, representative sequences and taxonomy assignments to the representative sequences of this study are available in figshare.com (https://figshare.com/s/ 5ec06b97fedfee01d5ac).

\section{Authors' contributions}

$\mathrm{Nl}$ analyzed the data, contributed reagents/materials/analysis tools, wrote the paper, prepared figures and/or tables, reviewed drafts of the paper. BV performed the experiments, contributed reagents/materials/analysis tools, wrote the paper. LDB, JDF and JKPV participated in the writing and drafting of the manuscript; DP conceived and designed the experiments, wrote the paper, reviewed drafts of the paper. All authors read and approved this final manuscript.

\section{Ethics approval}

Dairy cows that were donors of rumen fluid were maintained according to the ethics committee and IACUC standards for the University of Pennsylvania (approval \#805538).

Consent for publication

Not applicable.

\section{Competing interests}

The authors declare that they have no competing interests.

\section{Publisher's Note}

Springer Nature remains neutral with regard to jurisdictional claims in published maps and institutional affiliations.

\section{Author details}

'Department of Clinical Studies, School of Veterinary Medicine, New Bolton Center, University of Pennsylvania, Kennett Square, PA 19348, USA.

${ }^{2}$ Department of Food Science, Pennsylvania State University, University Park, State College, PA 16802, USA. ${ }^{3}$ Penn State Hershey Cancer Institute, Hershey, PA 17033, USA.

Received: 7 March 2017 Accepted: 22 August 2017

Published online: 30 August 2017

\section{References}

1. Bergman $E$. Energy contributions of volatile fatty acids from the gastrointestinal tract in various species. Physiol Rev. 1990;70(2):567-90.

2. Hackmann TJ, Firkins JL. Maximizing efficiency of rumen microbial protein production. Front Microbiol. 2015;6

3. Bargo F, Muller L, Delahoy J, Cassidy T. Performance of high producing dairy cows with three different feeding systems combining pasture and total mixed rations. J Dairy Sci. 2002;85(11):2948-63.

4. Dewhurst R, Davies D, Merry R. Microbial protein supply from the rumen. Anim Feed Sci Technol. 2000;85(1):1-21.

5. Hoover W, Stokes S. Balancing carbohydrates and proteins for optimum rumen microbial yield. J Dairy Sci. 1991;74(10):3630-44.

6. Goering HK, Van Soest PJ. Forage fiber analyses (apparatus, reagents, prcedures, and some applications). USDA Agr Handb. 1970;

7. Sniffen C, O'connor J, Van Soest P, Fox D, Russell J. A net carbohydrate and protein system for evaluating cattle diets: II. Carbohydrate and protein availability. J Anim Sci. 1992;70(11):3562-77.

8. Allen M. Maximizing digestible intake of corn silage-based diets. Part 2. In: Mich Dairy Rev. vol. 14. Michigan: Michigan State University; 2009. p. 4-6.

9. Khafipour E, Li S, Plaizier JC, Krause DO. Rumen microbiome composition determined using two nutritional models of subacute ruminal acidosis. Appl Environ Microbiol. 2009;75(22):7115-24.

10. Martin SA. Manipulation of ruminal fermentation with organic acids: a review. J Anim Sci. 1998;76(12):3123-32.

11. Hassanat F, Gervais R, Julien C, Massé D, Lettat A, Chouinard P, Petit H, Benchaar C. Replacing alfalfa silage with corn silage in dairy cow diets: Effects on enteric methane production, ruminal fermentation, digestion, $\mathrm{N}$ balance, and milk production. J Dairy Sci. 2013;96(7):4553-67.

12. Lettat A, Hassanat F, Benchaar C. Corn silage in dairy cow diets to reduce ruminal methanogenesis: Effects on the rumen metabolically active microbial communities. J Dairy Sci. 2013;96(8):5237-48.

13. Jami E, Mizrahi I. Composition and similarity of bovine rumen microbiota across individual animals. PLoS One. 2012;7(3):e33306.

14. Jami E, White BA, Mizrahi I. Potential role of the bovine rumen microbiome in modulating milk composition and feed efficiency. PLoS One. 2014:9(1):e85423.

15. Jewell KA, McCormick CA, Odt CL, Weimer PJ, Suen G. Ruminal bacterial community composition in dairy cows is dynamic over the course of two lactations and correlates with feed efficiency. Appl Environ Microbiol. 2015; 81(14):4697-710.

16. Lima FS, Oikonomou G, Lima SF, Bicalho ML, Ganda EK, de Oliveira Filho JC, Lorenzo G, Trojacanec P, Bicalho RC. Prepartum and postpartum rumen fluid microbiomes: characterization and correlation with production traits in dairy cows. Appl Environ Microbiol. 2015;81(4):1327-37. 
17. Pitta DW, Indugu N, Kumar S, Vecchiarelli B, Sinha R, Baker LD, Bhukya B, Ferguson JD. Metagenomic assessment of the functional potential of the rumen microbiome in Holstein dairy cows. Anaerobe. 2016;38:50-60.

18. Pitta D, Kumar S, Vecchiarelli B, Shirley D, Bittinger K, Baker L, Ferguson J, Thomsen N. Temporal dynamics in the ruminal microbiome of dairy cows during the transition period. J Anim Sci. 2014a;92(9):4014-22.

19. Kumar S, Indugu N, Vecchiarelli B, Pitta DW. Associative patterns among anaerobic fungi, methanogenic archaea, and bacterial communities in response to changes in diet and age in the rumen of dairy cows. Front Microbiol. 2015;6:781.

20. Cersosimo LM, Bainbridge ML, Kraft J, Wright A-DG. Influence of periparturient and postpartum diets on rumen methanogen communities in three breeds of primiparous dairy cows. BMC Microbiol. 2016;16(1):78.

21. Bainbridge ML, Cersosimo LM, Wright A-DG, Kraft J. Rumen bacterial communities shift across a lactation in Holstein, Jersey and Holstein $\times$ Jersey dairy cows and correlate to rumen function, bacterial fatty acid composition and production parameters. FEMS Microbiol Ecol. 2016:92(5).

22. Shabat SKB, Sasson G, Doron-Faigenboim A, Durman T, Yaacoby S, Miller MEB, White BA, Shterzer N, Mizrahi I. Specific microbiome-dependent mechanisms underlie the energy harvest efficiency of ruminants. ISME J. 2016;

23. Li F, Li Z, Lei S, d Ferguson J, Cao Y, Yao J, Sun F, Wang X, Yang T. Effect of dietary physically effective fiber on ruminal fermentation and the fatty acid profile of milk in dairy goats. J Dairy Sci. 2014;97(4):2281-90.

24. Minuti A, Palladino A, Khan M, Alqarni S, Agrawal A, Piccioli-Capelli F, Hidalgo F, Cardoso F, Trevisi E, Loor J. Abundance of ruminal bacteria, epithelial gene expression, and systemic biomarkers of metabolism and inflammation are altered during the peripartal period in dairy cows. J Dairy Sci. 2015:98(12):8940-51.

25. Wang X, Li X, Zhao C, Hu P, Chen H, Liu Z, Liu G, Wang Z. Correlation between composition of the bacterial community and concentration of volatile fatty acids in the rumen during the transition period and ketosis in dairy cows. Appl Environ Microbiol. 2012;78(7):2386-92.

26. AOAC. Official methods of analysis, vol. I. 15th ed. Arlington: AOAC; 1990.

27. VanSoest P, Robertson J, Lewis B, et al. J Dairy Sci. 1991;74(10):3583-97.

28. Lodge-Ivey S, Browne-Silva J, Horvath M. Technical note: bacterial diversity and fermentation end products in rumen fluid samples collected via oral lavage or rumen cannula. J Anim Sci. 2009;87(7):2333-7.

29. Dollive S, Peterfreund GL, Sherrill-Mix S, Bittinger K, Sinha R, Hoffmann C, Nabel CS, Hill DA, Artis D, Bachman MA. A tool kit for quantifying eukaryotic rRNA gene sequences from human microbiome samples. Genome Biol. 2012;13:R60

30. Caporaso JG, Kuczynski J, Stombaugh J, Bittinger K, Bushman FD, Costello EK, Fierer N, Pena AG, Goodrich JK, Gordon Jl. QIIME allows analysis of highthroughput community sequencing data. Nat Methods. 2010a;7(5):335-6.

31. Team RC. R: A language and environment for statistical computing. Vienna: R Foundation for Statistical Computing; 2013. ISBN 3-900051-07-0; 2016

32. Edgar RC. Search and clustering orders of magnitude faster than BLAST. Bioinformatics. 2010;26(19):2460-1.

33. Caporaso JG, Bittinger K, Bushman FD, DeSantis TZ, Andersen GL, Knight R PyNAST: a flexible tool for aligning sequences to a template alignment. Bioinformatics. 2010b;26(2):266-7.

34. Price MN, Dehal PS, Arkin AP. FastTree 2-approximately maximum-likelihood trees for large alignments. PLoS One. 2010;5(3):e9490.

35. McDonald D, Price MN, Goodrich J, Nawrocki EP, DeSantis TZ, Probst A, Andersen GL, Knight R, Hugenholtz P. An improved Greengenes taxonomy with explicit ranks for ecological and evolutionary analyses of bacteria and archaea. ISME J. 2012;6(3):610-8.

36. Wang Q, Garrity GM, Tiedje JM, Cole JR. Naive Bayesian classifier for rapid assignment of rRNA sequences into the new bacterial taxonomy. Appl Environ Microbiol. 2007;73(16):5261-7.

37. Anderson MJ. A new method for non-parametric multivariate analysis of variance. Austral Ecol. 2001:26(1):32-46.

38. Lozupone C, Knight R. UniFrac: a new phylogenetic method for comparing microbial communities. Appl Environ Microbiol. 2005;71(12):8228-35.

39. Wei T, Simko V: Visualization of a Correlation Matrix. R package version 0.77. 2016.

40. Dairy Research Management Services (DRMS) Records [http://www.drms.org/]].

41. Kiddy CA. A review of research on genetic variation in physiological characteristics related to performance in dairy cattle. J Dairy Sci. 1979;62(5): 818-24

42. Grant $\mathrm{R}$, Albright J. Feeding behavior and management factors during the transition period in dairy cattle. J Anim Sci. 1995;73(9):2791-803.
43. McCann JC, Wickersham TA, Loor JJ. High-throughput methods redefine the rumen microbiome and its relationship with nutrition and metabolism. Bioinformatics and biology insights. 2014;8

44. Evans CC, LePard KJ, Kwak JW, Stancukas MC, Laskowski S, Dougherty J, Moulton L, Glawe A, Wang Y, Leone V. Exercise prevents weight gain and alters the gut microbiota in a mouse model of high fat diet-induced obesity. PLoS One. 2014;9(3):e92193.

45. Pope P, Smith W, Denman S, Tringe S, Barry K, Hugenholtz P, McSweeney C, McHardy A, Morrison M. Isolation of Succinivibrionaceae implicated in low methane emissions from Tammar wallabies. Science. 2011;333(6042):646-8.

46. Van Gylswyk N, Hippe H, Rainey F. Schwartzia succinivorans gen. nov., sp. nov., another ruminal bacterium utilizing succinate as the sole energy source. Int J Syst Evol Microbiol. 1997:47(1):155-9.

47. McCabe MS, Cormican P, Keogh K, O'Connor A, O'Hara E, Palladino RA, Kenny DA, Waters SM. Illumina MiSeq phylogenetic amplicon sequencing shows a large reduction of an uncharacterised succinivibrionaceae and an increase of the Methanobrevibacter gottschalkii Clade in feed restricted cattle. PLoS One. 2015;10(7):e0133234

48. Liu H, Zhao K, Liu J. Effects of glucose availability on expression of the key genes involved in synthesis of milk fat, lactose and glucose metabolism in bovine mammary epithelial cells. PLoS One. 2013;8(6):e66092.

49. Romero-Pérez GA, Ominski KH, McAllister TA, Krause DO. Effect of environmental factors and influence of rumen and hindgut biogeography on bacterial communities in steers. Appl Environ Microbiol. 2011;77(1):258-68.

50. McCartney D, Vaage A. Comparative yield and feeding value of barley, oat and triticale silages. Can J Anim Sci. 1994;74(1):91-6.

51. Pitta D, Pinchak W, Dowd S, Dorton K, Yoon I, Min B, Fulford J, Wickersham T, Malinowski D. Longitudinal shifts in bacterial diversity and fermentation pattern in the rumen of steers grazing wheat pasture. Anaerobe. 2014b;30:11-7.

52. Pitta DW, Parmar N, Patel AK, Indugu N, Kumar S, Prajapathi KB, Patel AB, Reddy B, Joshi C. Bacterial diversity dynamics associated with different diets and different primer pairs in the rumen of Kankrej cattle. PLoS One. 2014c; 9(11):e111710

53. NRC. Nutrient requirements of dairy cattle. Washington, DC: National Academy of Sciences; 2001. p. 381.

54. Petri RM, Schwaiger T, Penner GB, Beauchemin KA, Forster RJ, McKinnon JJ, McAllister TA. Characterization of the core rumen microbiome in cattle during transition from forage to concentrate as well as during and after an acidotic challenge. PLoS One. 2013;8(12):e83424.

55. Weimer PJ. Redundancy, resilience, and host specificity of the ruminal microbiota: implications for engineering improved ruminal fermentations. Front Microbiol. 2015;6:296.

56. Edwards JE, N.R. McEwan, A.J. Travis, Wallace RJ: 16S rDNA library-based analysis of ruminal bacterial diversity. Antonie Van Leeuwenhoek 2004, 86: 263-281.

57. Wallace RJ, Rooke JA, McKain N, Duthie C-A, Hyslop JJ, Ross DW, Waterhouse A, Watson M, Roehe R. The rumen microbial metagenome associated with high methane production in cattle. BMC Genomics. 2015;16(1):1.

\section{Submit your next manuscript to BioMed Central and we will help you at every step:}

- We accept pre-submission inquiries

- Our selector tool helps you to find the most relevant journal

- We provide round the clock customer support

- Convenient online submission

- Thorough peer review

- Inclusion in PubMed and all major indexing services

- Maximum visibility for your research

Submit your manuscript at www.biomedcentral.com/submit
C) Biomed Central 